\title{
Effectiveness of Sand-Therapy on the Attenuation of Separation anxiety Signs in Pre-School Children
}

\author{
Arghavan Shariat (Corresponding author) \\ Department of Psychology, Islamic Azad University of Shahrekord Branch, Iran \\ E-mail: ashariat2013@gmail.com \\ Amir Ghamarani \\ Faculty of Education and Psychology, University of Isfahan, Isfahan, Iran \\ Ahmad Yarmohammadian \\ Faculty of Education and Psychology, University of Isfahan, Isfahan, Iran \\ Tayyebe Sharifi \\ Department of Psychology, Islamic Azad University of Shahrekord Branch, Iran
}

Received: 05-12- 2014

doi:10.7575/aiac.ijkss.v.3n.1p.15
Accepted: 19-01- 2015

URL: http://dx.doi.org/10.7575/aiac.ijkss.v.3n.1p.15
Published: 31-01- 2015

\begin{abstract}
Background and Objective: The present research was conducted with the aim of determining effect of Sand-therapy on the attenuation of separation anxiety signs among pre-school children in Isfahan, Iran. Methods: The statistical society consists of all pre-school children who had separation anxiety disorder and Among100 children, 30 persons were selected using available sampling. The method of this research is quasi-experimental with one group and pre-test and post-test plan. After performing pre-test of separation anxiety disorder scale, the experimental group were trained under sand-therapy training in 10 sessions of 60 minutes for a period of two months and after that, post-test of separation anxiety disorder scale was performed. The research tool consists of the questionnaire CSI-4 of child's morbid signs. Wilcoxon method was used to analysis the results. Results: The research findings showed that there was a meaningful different $(\mathrm{P}=0.008)$ between pre- test $\&$ post-test scores of anxiety signs for study group.Conclusion: As a practical message, we can mention that sand therapy is as an interesting and practical playing for the children and it is a meaningful therapy related to attenuation of separation anxious signs.
\end{abstract}

Keywords: Sand therapy, separation anxiety, pre-school-children

\section{Introduction}

Anxiety disorder is one of the most common emotional and psychological disorders among children and adolescents. Epidemiologic studies indicated that about 8\%- 12\% of children and 5\%- 10\%of adolescents confront with one of diagnostic criteria for anxiety disorder, which leads to dysfunction in normal life procedure, and performance of a child(Puliafico, Comer, \& Pincus, 2012). Anxiety disorder in children and adolescents has significant negative outcomes in personal, educational and social adoptability. In addition, the evidences indicate that childhood anxiety disorder is not a transient phenomenon and it will continue to adolescence and adulthood in case of lack of treatment; therefore, the person will face with many problems(Biederman et al., 2014). Therefore, it is necessary to preparing basis of effective and proper treatment in addition to identifying such children.

Clure et.al(McClure, Pope, Hoberman, Pine, \& Leibenluft, 2014)indicated in a research that children with anxiety disorder probably receive diagnostic criteria seven years after start of the disorder; therefore, anxiety disorder in childhood may become chronic and permanent.

Anxiety disorder of separation is specified to children and it is considered in DSM-IV as a distinct category. Anxiety about separation means child feels agitation expecting or after separating from someone whom is dependent to (Axline, 2012; Green, Myrick, \& Crenshaw, 2013).

The children who have separation anxiety show terrific anxiety or even panic. These children may not be able to stay in a room lonely then they refuse to meet family friends or avoid to going to school. When these children are asked that why they are frightened, they may state fear of getting lost and never finding their parents or they may be worry about accidents and illnesses, which may happen to themselves or their parents. Often, these children complain about nausea, headache, abnormal pains or heart fast beat(Shariat, Shariat, Abedi, \& Tamrin, n.d.). In other times, when it is time to separate, their behavior contains anxiety or panic signs(Haen, 2011; Puliafico et al., 2012).

Playing for children is the same as speech for adults. Game is a tool for expressing emotions, establishing relationships, describing experiences, disclosing wishes and self-actualization. The game activity is actually effort of the child to cope 
with the environment and he/she finds himself/herself through it and understands the world(Axline, 2012; Ito, 2014). Children game is not just for fun; rather we should consider it as the most serious act of children because it is an evaluable activity. Playing is a pleasurable and amusing activity, which is necessary for comprehensive growth of the child. Young children cannot state their thoughts and opinions easily; therefore, they express themselves through playing. Playing is a natural way of learning. Child experiences, concludes and learns through playing. Playing nurtures power of innovation, creativity and concentration in child and help him to discover relationship between objects and surrounding(Meany-Walen, Bratton, \& Kottman, 2014). In fact, since children communicate with adults and their surrounding through playing and since playing is an effective factor in reducing fear and anxiety of children such as separation anxiety, we can probably use it in treating children with separation anxiety. Therefore, probably effect of games such as playing with sand, playing with paste, clay pottery, playing with Lego, finger painting etc can be an effective factor in eradicating or reducing symptoms of separation anxiety in children.

Playing with sand is a kind of indirect game-therapy, therapist has a facilitator role, and children can create freely their excitement and mental images through sand box and miniatures in there. For the therapist, regardless his/her orientation, this method of therapy is valuable. Maybe sand-therapy found a new place in world of therapy especially in treatment of children(Schaefer \& Drewes, 2011; Wen, Risheng, \& Lina, 2013). History of sand-therapy is back to Margaret Onflow who was a pediatrician(Biederman et al., 2014). In many techniques, which are used in sand lots, works of Margaret lowenfield (in the name of the world technique) were the inspiration(Dehghani, Amiri, Molavi, \& Neshat-Doost, 2013). Lowenfield started her psychoanalytic activities with children in 1925 and she founded institute of child psychology (4). She introduced it as technique of problematic and nervous children(Horwitz \& Wakefield, 2012). Due to effect of H-GWell (ground games), Lowenfield collected small toys and gave them to her clients, while these toys were isolated in a box called magic box(Lewis et al., 2008).

Sand-therapy method is highly examined in school environment (Silverman \& Field, 2011) and it took attention of many therapist, consolers and researchers(Zhao, Xing, \& Wang, 2012). Therefore, the main problem of the present research is as follow. Is sand-therapy an effective method to reducing signs of separation anxiety in pre-school children?

In a study, Schaefer(Schaefer \& Drewes, 2011) indicated that sand-therapy is effective. The results of their research showed that sand-therapy gave the opportunity to the referral to show excitements and unconscious imaginations and it led to resolving problem of insecure dependency to parents. Therefore, the aim of the present research is determining effectiveness of sand-therapy on reducing separation anxiety of pre-school children.

\section{Methods}

This research was aquasi-experimental, which was conducted using the research design of posttest-pretest with a group. An available sampling was conducted to select the participants and the comparison was done within group and followed an internal parallel model. The scores of questionnaire were contrasted in pre test and post test. The results would be meaningful, if the $\mathrm{P}$ value was less than 0.05.Moral considerations were observed, so at the start stages of performing the test were completely described for parents of pre-school children and then, a written consent including conducting sand-therapy stages. In addition, the present research was done under the supervision of psychology and educative sciences in Isfahan University. The subjects were given a clear explanation of the objectives of the study, as well as the potential risks involved(Jabarouti, Shariat, \& Shariat, 2014), and consent forms (parental consent forms) were obtained for all subjects. All procedures performed in this study were in accordance with the ethical standards of the 1964 Helsinki declaration.

\subsection{Statistical society, sample and sampling method}

Statistical society of the present research was 4-6 years old children with separation anxiety disorder and 100 children were chosen as primary samples among Isfahan kindergartens randomly. Finally, 30 children with conclusive signs of separation anxiety disorder were chosen as final samples using child's morbid signs questionnaire (CSI-4). The children with pervasive anxiety disorder, social anxiety disorder etc were excluded from the research.

\subsection{Instruments}

Child's morbid signs questionnaire (CSI-4) separation anxiety subscale was used to evaluating separation anxiety disorder, questions of 86-95 in CSI-4 questionnaire in parent specific form were used. Scoring method of this questionnaire includes never, sometimes, often and most of the time that are marked by parents based on level of separation anxiety of the child. Reliability and validity of this scale were considered suitable in many studies in other countries(Haen, 2011; Meany-Walen et al., 2014). In Iran, in research of Neshatdoust et al. (21), validity of this questionnaire was obtained using fifty-fifty method for teachers as 0.91 and for parents as 0.85 . According to the previous research (Wen et al., 2013)reliability of parent checklist was defined 90 through retest.

\subsection{Protocol}

After evaluating the sample group by test of separation anxiety disorder, 10 sessions of send-therapy interventions were conducted on these children based on Margaret Onflow's sand-therapy pattern. 
Table 1. A brief overview of sand-therapy sessions

\begin{tabular}{ll}
\hline Sessions & \multicolumn{1}{c}{ Sessions' topic } \\
\hline First & $\begin{array}{l}\text { After greeting with children, we tried to establish an emotional and } \\
\text { friendly relationship with them }\end{array}$ \\
\hline Second & $\begin{array}{l}\text { Making trust in children through free choosing type of games }+ \\
\text { encouraging children to play with sand and gravel }\end{array}$ \\
\hline Third & $\begin{array}{l}\text { Simulating home and kindergarten circumstance (in order to reducing } \\
\text { children anxiety from new environment and enforcing feeling secure } \\
\text { in children) }\end{array}$ \\
\hline Fourth & Simulating stressful spaces for children \\
\hline Fifth & Trying to reducing children anxiety from playing with them \\
\hline Sixth & $\begin{array}{l}\text { Providing new educational strategies to eliminating boredom and } \\
\text { making variety in children }\end{array}$ \\
\hline Seventh & Playing role in order to reducing children anxiety \\
\hline Eighth & Gradually improvement in signs of anxiety in children \\
\hline Ninth & Enthusiasm for kindergarten space without anxiety \\
\hline Tenth & Reducing signs of separation anxiety in children \\
\hline
\end{tabular}

\section{Results}

Average anxiety score was $21.6 \pm 2.17$ before the test and $16.4 \pm 3.47$ after the test. According to Wilcoxon test, there was a meaningful difference before and after the intervention. Difference of average anxiety score was $5.2 \pm 2.7$ with domain of 0-9 after the invention. Accordingly, sand-therapy was able to reduce the anxiety in this population $(\mathrm{p}=0.008)$. It means, the protocol of sand therapy, was able to change the scores of their questionnaire positively.

Since questions of the questionnaire were designed in Likert rating scale, wilcoxon rating test was used to evaluating changes in each option after intervention and obtained results of this test is shown in table 1 for each option. According to the mentioned table, average of positive (reduced) rates was 4.2 and average of negative (increased) rated was 3.5 and sum of positive rates was 21 and sum of negative rates was 7; but difference between before and after intervention was not meaningful $(\mathrm{p}=0.21)$. In addition, sum of positive and negative rates for second option were 16.5 and 4.5 , respectively and there was no meaningful difference in this option after intervention $(p=0.19)$. Sum of positive and negative rates for third question were 18.5 and 9.5 , respectively and the difference before and after intervention was not meaningful $(\mathrm{p}=0.43)$.

In forth options, sum of positive and negative rates were 33 and 3, respectively and the difference was meaningful after treatment $(\mathrm{p}=0.31)$. For fifth option, sum of positive and negative rates were 30.5 and 5.5 , respectively; but the difference before and after intervention was not meaningful $(\mathrm{p}=0.08)$. Sum of positive and negative rates for sixth question were 16 and 5, respectively and no meaningful difference after and before intervention was not observed $(\mathrm{p}=0.24)$. In seventh question, sum of positive rates was 36 and there was no negative rate and the difference before and after intervention was meaningful $(\mathrm{p}=0.009)$. In eighth option, there was no meaningful difference before and after treatment $(\mathrm{p}=0.41)$ as sum of positive and negative rates were 4.5 and 1.5 , respectively. In ninth question, sand-therapy had no effect on enuresis and sum of positive and negative rates were 0 and 1, respectively. Finally, for tenth option, sum of positive and negative rates were 1 and 0 and there was no meaningful difference after treatment $(\mathrm{p}=0.32)$.

Table 2. Mean, sum and significance level of rates related to intensity of anxiety signs before and after sand-therapy intervention

\begin{tabular}{|c|c|c|c|c|c|c|}
\hline \multirow[t]{2}{*}{ Items } & \multicolumn{2}{|c|}{ Average rating } & \multicolumn{2}{|c|}{ Rate sum } & \multicolumn{2}{|c|}{ Significance level } \\
\hline & Positive & Negative & Positive & Negative & $\mathrm{Z}$ & $\mathrm{P}$ \\
\hline $\begin{array}{l}\text { 1. Every time he/sheisgoing } \\
\text { to be away from home or } \\
\text { his/her parents, she/he is } \\
\text { very upset and sad. }\end{array}$ & 4.2 & 3.5 & 21 & 7 & -1.27 & 0.21 \\
\hline $\begin{array}{l}\text { 2. he/she is worried and sad } \\
\text { about possible harm to } \\
\text { his/her parents or about their } \\
\text { leaving and never coming } \\
\text { back. }\end{array}$ & 3.3 & 4.5 & 16.5 & 4.5 & -1.3 & 0.19 \\
\hline
\end{tabular}




\begin{tabular}{|c|c|c|c|c|c|c|}
\hline $\begin{array}{l}3 \text {. she/he is worried and sad } \\
\text { about happening and } \\
\text { unpleasant accident or event } \\
\text { leading to his/her separation } \\
\text { from his/her parents }\end{array}$ & 4.63 & 17.3 & 18.5 & 9.5 & -0.78 & 0.43 \\
\hline $\begin{array}{l}\text { 4. he/she tries to refuse to } \\
\text { going to school so he/she } \\
\text { can stay with his/her parents }\end{array}$ & 4.71 & 3 & 33 & 3 & -2.2 & 0.0131 \\
\hline $\begin{array}{l}\text { 5. he/she is afraid to stay } \\
\text { home alone or with a } \\
\text { stranger (nurse or } \\
\text { babysitter). }\end{array}$ & 4.36 & 5.5 & 30.5 & 5.5 & -1.78 & 0.08 \\
\hline $\begin{array}{l}\text { 6. he/she is afraid of } \\
\text { sleeping when his/her } \\
\text { parents are away. }\end{array}$ & 2.3 & 5 & 16 & 5 & -1.18 & 0.24 \\
\hline $\begin{array}{l}\text { 7. he/she sees nightmare } \\
\text { about possibility of his/her } \\
\text { parents' separation }\end{array}$ & 4.5 & 00 & 36 & 00 & -2.6 & 0.009 \\
\hline $\begin{array}{l}\text { 8. Whenever he/she is } \\
\text { supposed to be separated } \\
\text { from his/herparents, he/she } \\
\text { complains of feeling nausea }\end{array}$ & 2.25 & 1.5 & 4.5 & 1.5 & -0.82 & 0.41 \\
\hline 9. he/she has enuresis & 00 & 1 & 00 & 1 & -1 & 0.32 \\
\hline $\begin{array}{l}\text { 10. he/she pees or defecates } \\
\text { in day hours under his/her } \\
\text { pants }\end{array}$ & 1 & 00 & 1 & 00 & -1 & 0.32 \\
\hline
\end{tabular}

Table 3. Distribution of anxiety signs before and after intervention

\begin{tabular}{|c|c|c|c|c|c|}
\hline Items & Time level & never & Sometimes & often & $\begin{array}{l}\text { Most } \\
\text { of the } \\
\text { time }\end{array}$ \\
\hline \multirow{2}{*}{$\begin{array}{l}\text { 1. Every time he/she is going to be away } \\
\text { from home or his/her parents, she/he is very } \\
\text { upset and sad. }\end{array}$} & $\begin{array}{l}\text { Before } \\
\text { intervention }\end{array}$ & (0) 0 & (60) 6 & (30) 3 & (10) 1 \\
\hline & $\begin{array}{l}\text { After } \\
\text { intervention }\end{array}$ & (10) 1 & (70) 7 & (20) 2 & (0) 0 \\
\hline \multirow{2}{*}{$\begin{array}{l}\text { 2. he/she is worried and sad about possible } \\
\text { harm to his/her parents or about their leaving } \\
\text { and never coming back. }\end{array}$} & $\begin{array}{l}\text { Before } \\
\text { intervention }\end{array}$ & (10) 1 & (40) 4 & (40) 4 & (10) 1 \\
\hline & $\begin{array}{l}\text { after } \\
\text { intervention }\end{array}$ & (40) 4 & (40) 4 & (10) 1 & (10) 1 \\
\hline \multirow{2}{*}{$\begin{array}{l}\text { 3. she/he is worried and sad about } \\
\text { happening and unpleasant accident or event } \\
\text { leading to his/her separation from his/her } \\
\text { parents }\end{array}$} & $\begin{array}{l}\text { Before } \\
\text { intervention }\end{array}$ & (40) 4 & (20) 2 & (10) 1 & (30) 3 \\
\hline & $\begin{array}{l}\text { After } \\
\text { intervention }\end{array}$ & (20) 2 & (60) 6 & (20) 2 & (0) 0 \\
\hline \multirow{2}{*}{$\begin{array}{l}\text { 4. he/she tries to refuse to going to school so } \\
\text { he/she can stay with his/her parents. }\end{array}$} & $\begin{array}{l}\text { Before } \\
\text { intervention }\end{array}$ & (20) 2 & (40) 4 & (20) 2 & (20) 2 \\
\hline & $\begin{array}{l}\text { After } \\
\text { intervention }\end{array}$ & (70) 7 & (20) 2 & (10) 1 & (0) 0 \\
\hline \multirow{2}{*}{$\begin{array}{l}\text { 5. he/she is afraid to stay home alone or with } \\
\text { a stranger (nurse or babysitter). }\end{array}$} & $\begin{array}{l}\text { Before } \\
\text { intervention }\end{array}$ & (10) 1 & (20) 2 & (60) 6 & (10) 1 \\
\hline & $\begin{array}{l}\text { after } \\
\text { intervention }\end{array}$ & (50) 5 & (30) 3 & (20) 2 & (0) 0 \\
\hline \multirow{2}{*}{$\begin{array}{l}\text { 6. he/she is afraid of sleeping when his/her } \\
\text { parents are away. }\end{array}$} & $\begin{array}{l}\text { Before } \\
\text { intervention }\end{array}$ & (10) 1 & (30) 3 & (20) 2 & (40) 4 \\
\hline & $\begin{array}{l}\text { After } \\
\text { intervention }\end{array}$ & (40) 4 & (10) 1 & (20) 2 & (30) 3 \\
\hline
\end{tabular}




\begin{tabular}{|c|c|c|c|c|c|}
\hline \multirow{2}{*}{$\begin{array}{l}\text { 7. he/she sees nightmare about possibility of } \\
\text { his/her parents' separation }\end{array}$} & $\begin{array}{l}\text { Before } \\
\text { intervention }\end{array}$ & (20) 2 & (40) 4 & (30) 3 & (10) 1 \\
\hline & $\begin{array}{l}\text { After } \\
\text { intervention }\end{array}$ & (80) 8 & (20) 2 & (0) 0 & (0) 0 \\
\hline \multirow{2}{*}{$\begin{array}{l}\text { 8. Whenever he/she is supposed to be } \\
\text { separated from his/her parents, he/she } \\
\text { complains of feeling nausea }\end{array}$} & $\begin{array}{l}\text { Before } \\
\text { intervention }\end{array}$ & (70) 7 & (20) 2 & (10) 1 & (0) 0 \\
\hline & $\begin{array}{l}\text { after } \\
\text { intervention }\end{array}$ & (80) 8 & (20) 2 & (0) 0 & (0) 0 \\
\hline \multirow{2}{*}{ 9. he/she has enuresis } & $\begin{array}{l}\text { Before } \\
\text { intervention }\end{array}$ & (70) 7 & (30) 3 & (0) 0 & (0) 0 \\
\hline & $\begin{array}{l}\text { After } \\
\text { intervention }\end{array}$ & (70) 7 & (20) 2 & (10) 1 & (0) 0 \\
\hline \multirow{2}{*}{$\begin{array}{l}\text { 10. he/she pees or defecates in day hours } \\
\text { under his/her pants }\end{array}$} & $\begin{array}{l}\text { Before } \\
\text { intervention }\end{array}$ & (90) 9 & (0) 0 & (0) 0 & (10) 1 \\
\hline & $\begin{array}{l}\text { After } \\
\text { intervention }\end{array}$ & (90) 9 & (10) 1 & (0) 0 & (0) 0 \\
\hline
\end{tabular}

\section{Discussion and conclusion}

The main aim of this research is evaluating effect of sand-therapy on reducing signs of separation anxiety disorder in pre-school children in city of Isfahan; therefore, this technique was performed on this group of children. Examination of this research indicated that sand-therapy could be used to treating separation anxiety disorder in children in order to reducing this disorder and according to obtained results, we cannot just give the sand to the children in order to sandtherapy. Educational experience showed that anxious child does not enjoy playing with sand and she/he refuses to do that. Therefore, this experiment was conducted using another way such as playing with paste, clay pottery, using finger painting or logo. It was shown that we should use complementary games to make sand-therapy easy for children using other methods. Some games such as playing with paste, playing with clay pottery and finger paintings were provided to preparing children and in fact, these methods were the appropriate strategy for accepting playing with sand. According to significant improvement and obtained results, we can expect to use sand-therapy as an effective method for improving children disorders such as aggression, withdrawal, nail biting, bed-wetting and children anxiety disorders such as separation anxiety disorder. In addition, this method can be used in all kindergarten and schools to discharging energy of children and according to its effective role, we can use it to eliminating fears and anxieties in children. Collectively, findings of this research are consistent with results of other researchers as follow.

Oak Lander (1) believes that young children accept this method due to familiarity with sand and gravel components. In addition, playing with sand is a kind of game that all children of the world are familiar with it. Axline and Hean(Axline, 2012; Haen, 2011)consider sand lot as a powerful tool, which releases oppressed energies and turns them to positive and effective properties. Puliafico (Puliafico et al., 2012)states that playing with sand is healing and healing is the final objective of consolers and therapists. Wen (Wen et al., 2013) considers sand lot as an intervention method, which its risk is low and its success is high, so it can be used in expert realm of teachers and consolers. Dehghani(Dehghani et al., 2013)found that this procedure is simple and harmless and it contains a direct express without need to speaking. Keller (Keller et al., 1992) found that sand lot helps children to release their hopelessness, stresses, insecurities, aggressions, fears, confusions and bewilderments.

Some of limitations of this research were lack of sample group and few numbers of available children with separation anxiety disorder andalso, as the researchers couldn't control the cooperation of participants, it could have a negative effect on the results.

As a practical conclusion, it is recommended that sand-therapy will performed for other groups of children such as children with ADHD disorder and children with confrontment disobedience disorder. It will be more effective and beneficial, if the parents be taught about the related methods and conduct it at home for their children. It is recommended that parents follow sand-therapy intervention along with kindergarten and school to avoiding pause between treatment hours and sessions.

\section{Acknowledgement}

I would like to thank psychology and educational sciences department in Isfahan University. Special thanks to Dr. Ardalan Shariat, for reviewing the manuscript in spite of his busy schedule. 


\section{References}

Axline, V. M. (2012). Play therapy. Ballantine Books, 2, 18-24.

Biederman, J., Faraone, S. V, Hirshfeld-Becker, D. R., Friedman, D., Robin, J. A., \& Rosenbaum, J. F. (2014). Patterns of psychopathology and dysfunction in high-risk children of parents with panic disorder and major depression. Am Psychiatric Assoc, 38-47.

Dehghani, F., Amiri, S., Molavi, H., \& Neshat-Doost, H. T. (2013). Psychometric properties of the Persian version of the screen for child anxiety-related emotional disorders (SCARED). Journal of Anxiety Disorders, 27(5), 469-474.

Green, E. J., Myrick, A. C., \& Crenshaw, D. A. (2013). Toward secure attachment in adolescent relational development: Advancements from sandplay and expressive play-based interventions. International Journal of Play Therapy, 22(2), 90.

Haen, C. (2011). The therapeutic use of superheroes in the treatment of boys. Engaging Boys in Treatment: Creative Approaches to the Therapeutic Process, 153-175.

Horwitz, A. V, \& Wakefield, J. C. (2012). All we have to fear: psychiatry's transformation of natural anxieties into mental disorders. Oxford University Press.

Ito, A. (2014). School Counselor Roles and Challenges in Japan. Journal of Asia Pacific Counseling, 4(2), $12-18$. Jabarouti, R., Shariat, A., \& Shariat, A. (2014). Effect of Persian Classic Poetry on the Level of Stress Hormone in Retired Academicians. Poetry Thrapy, 27(1), 1-9.

Keller, M. B., Lavori, P. W., Wunder, J., Beardslee, W. R., Schwartz, C. E., \& Roth, J. (1992). Chronic course of anxiety disorders in children and adolescents. Journal of the American Academy of Child \& Adolescent Psychiatry, 31(4), 595-599.

Lewis, M. A., Hove, M. C., Whiteside, U., Lee, C. M., Kirkeby, B. S., Oster-Aaland, L., ... Larimer, M. E. (2008). Fitting in and feeling fine: conformity and coping motives as mediators of the relationship between social anxiety and problematic drinking. Psychology of Addictive Behaviors, 22(1), 58-69.

McClure, E. B., Pope, K., Hoberman, A. J., Pine, D. S., \& Leibenluft, E. (2014). Facial expression recognition in adolescents with mood and anxiety disorders. Am Psychiatric Assoc, 12 (2), 32-48.

Meany-Walen, K. K., Bratton, S. C., \& Kottman, T. (2014). Effects of Adlerian Play Therapy on Reducing Students' Disruptive Behaviors. Journal of Counseling \& Development, 92(1), 47-56.

Puliafico, A. C., Comer, J. S., \& Pincus, D. B. (2012). Adapting parent-child interaction therapy to treat anxiety disorders in young children. Child and Adolescent Psychiatric Clinics of North America, 21(3), 607-619.

Schaefer, C. E., \& Drewes, A. A. (2011). The therapeutic powers of play and play therapy. Foundations of Play Therapy, 15-25.

Shariat, A., Shariat, A., Abedi, A., \& Tamrin, S. B. M. (n.d.). Physical activity as a prescription for the children with cerebral palsy. Russian Open Medical Journal, 3(1), 12-18.

Silverman, W. K., \& Field, A. P. (2011). Anxiety disorders in children and adolescents. Cambridge University Press, 3 , 34-36.

Wen, Z., Risheng, Z., \& Lina, C. (2013). The Process and Effects of Sandplay Therapy on Obsessive-Compulsive Symptoms in An Undergraduate. Archives of Sandplay Therapy, 26(2), 75-88.

Zhao, J., Xing, X., \& Wang, M. (2012). Psychometric properties of the Spence Children's Anxiety Scale (SCAS) in Mainland Chinese children and adolescents. Journal of Anxiety Disorders, 26(7), 728-736. 